Institute of Preventive Medicine; $£ 39,898$ for tsetse fly breeding at the University of Bristol; $£ 34,303$ for continuation of the preparation of the Flora of Tropical East Africa; $£ 62,933$ for continuation and expansion of agricultural research and land-use planning in Tanganyika; $£ 62,645$ for the Agricultural Research and Experimental Station, Nyasaland; $£ 56,550$ for establishment of a Citrus Research Unit in the British Caribbean; $£ 79,549$ for continuation of the Institute of Social and Economic Research in the West Indies; $£ 48,812$ for the Tropical Meta. bolism Research Unit in Jamaica; and $£ 20,934$ for soil surveys in British Guiana.

Development and welfare schemes of scientific interest include various contributions to Royal College, Nairobi, and the University College of East Africa, Makerere, as well as to the University College of the West Indies, and $£ 450,000$ for the construction of a College of Arts, Science and Technology, Malta, which received grants totalling more than $£ 5$ million during the year; $£ 421,907$ for intensification of African agriculture under the Swynnerton plan in Kenya, and a further $£ 102,804$ for the Veterinary Department; $£ 518,300$ for forestry development in Tanganyika, and $\mathfrak{£ 1 4 8 , 4 4 5}$ for continuation and expansion of agricultural research and land-use planning; $£ 246,000$ for development of broadcasting in Uganda; and $£ 429,132$ for soil conservation and land-use planning in Basutoland, 1960-64; $£ 18,877$ was contributed for the activities of the Commission for Technical Co-operation in Africa South of the Sahara and the Scientific Council for Africa South of the Sahara, and there were numerous contributions for education at secondary and primary levels.

\title{
THE NORFOLK BROADS
}

$\mathrm{O}^{\mathrm{N}}$ N August 1, the Minister of Housing and Local Government announced in the House of Commons that he had accepted the advice of the National Parks Commission that the unique character and complex problems of the Norfolk Broads make them unsuitable for designation as a National Park. It was therefore appropriate and timely that the British Association should discuss some of these problems during its Norwich meeting. Sections E (Geography) and K (Botany) held a joint symposium on September I at which the main contributions were made by Dr. Joyce Lambert of the Botany Department, University of Southampton, Mr. C. T. Smith of the Geography Department of the University of Cambridge, and Mr. Charles Green, an archæological consultant to the Ministry of Works.

The factors which render the Broads unsuitable as a National Park stem largely from the rapid changes which are taking place at the present time and which are all recent in effect, if not in origin. The silting up of the Broads, with the consequent overgrowth by vegetation had scarcely begun to reduce the area of open water when the Tithe Commission mapped the area in the mid-nineteenth century. The degeneration of mowing marsh into scrub and carr follows changes in agricultural practice in the past half-century. These physiographical and ecological developments clearly have a profound significance in terms of the ever-increasing use of the Broads as a holiday area, a use which introduces its own problems, both ecological and economic. While these changes have only recently forced thernselves on the attention of students of the broadland scene, they are bound up with the basic problems concerning the age and origin of the Broads, which formed major themes in the Norwich discussion and which involve rather longer periods of time.

Most nineteenth-century writers from Robbards and Taylor in the 1820's to Gregory in 1892, sought to intorpret the Broads as residual natural lakes resulting from the silting up of a 'great estuary', the three arms of which occupied the valleys of the Rivers Waveney, Yare and Bure. Many of these writers assumed that the 'great estuary' persisted well into historical times. A few workers sought to invoke glacial agencies. In 1952, J. N. Jennings published a monograph on The Origin of the Broads (No. 2 in the Royal Geographical Society's Research Series).
This was the first weighty piece of original research to appear for almost half $\mathbf{a}$ century and represented the results of several years labours, mainly in the valleys of the Bure and its tributary, the Ant Jennings suggested that the Broads can be explained in terms of a geologically very recent marine transgression during which a thick wedge of estuarine clay was laid down over the early valley peats of the Norfolk river valleys. He suggested that the Broads themselves were initiated as discontinuous lakes, lying in natural hollows in the peat, filled with water ponded back between the flanges of the clay and the upland valley margins (by-passed broads) or in tributary valleys the mouths of which were blocked by the clay (side-valley broads). Jennings examined the possibility, mooted on several occasions to explain particular broads, that all the Broads were manmade. For a variety of reasons he came to the conclusion that "a general theory based on peat cutting appears to be wholly unacceptable".

Almost before his monograph was in print, Jennings had modified his views in the light of new work. Dr. Lambert, with whom he had collaborated closely in work on the valleys of the Bure and the Ant, had obtained convincing evidence that the Broads of the Yare valley are artificial. She employed the same boring methods and the same pollen analysis technique, to determine the stratigraphy of the clays, peats and muds, as Jennings had used. A reconsideration of the evidence from the Bure and the Ant valleys suggested that deep extraction of peat in historical times was responsible for all the by-passed broads, though, for lack of evidence, the side-valley broads were not as yet included in the general theory. This recognition of the fact that most, if not all, of the Broads are man-made did not, of course, detract from Jennings's interpretation of the natural evolution of the river valleys in which the Broads are located.

In 1960, Jennings and Lambert published a re-appraisal of the whole problem of the evolution of the Broads. They found it "difficult, in view of the stratigraphical evidence to conceive a substantial alternative" to the theory that all the Broads are deep peat diggings which have been afterwards flooded. Breydon Water is excluded from this explanation since it is clearly not a broad in the accepted sense and is merely the surviving part of $a$ 
formerly more extensive Bure-Yare-Waveney estuary.

Evidence from the field of historical geography assembled by Mr. C. T. Smith and the results of archæological work, interpreted by Mr. Charles Green and $\mathrm{Mr}$. J. N. Hutchinson, supported the new hypothesis. The combined evidence was published under the title The Making of the Broads (No. 3 in the Royal Geographical Society's Research Series).

At the Norwich symposium, Dr. Lambert reviewed the physiographical and botanical evidence on which their findings are based. Boring has revealed that the basins in which the Broads lie have uniformly steep sides and virtually level floors with resulting rectangular profiles. Islands and peninsulas with similar vertical sides have exactly the same stratigraphy as the surrounding fenland. They are interpreted as balks left in the extraction of peat to a depth of 10-12 ft. In old surveys, including tithe and enclosure maps and in modern air photographs these islands and peninsulas can be correlated with boundaries between holdings.

Two of the more important difficulties in accepting human agencies to account for the existence of the Broads relate to the enormous amount of peat involved and the need to postulate changes in waterlevel, which would permit the excavation of peat to depths well below those of present-day workings, and eventually lead to the flooding of tho pits. Mr. C. T. Smith described the search for evidence which would resolve these difficulties. Nothing in the published records of broadland suggested an 'artificial' origin. The large-scale changes caused by the extraction of an estimated nine hundred million cubic feet of peat and the flooding of the workings appear to have made no impact on local tradition and folk-lore. However, a careful and detailed study of documents and maps supplied strong circumstantial evidence in support of the deductions based on the stratigraphy. References to turbary and the sale and consumption of turves show that large-scale peat digging was well under way by the twelfth century. Much of the consumption must have gone unrecorded but examination of terriers, deeds, account rolls and registers, such as those of Norwich Cathedral Priory and St. Benet's Abbey, give an indication of the scale of operations. The purchase of 400,000 turves by Norwich Cathedral Priory in 1316 is typical. These same records also show that by the beginning of the fourteenth century the flooding of the turf pits had begun. While extraction continued well into the fifteenth century it was increasingly difficult and expensive, and involved first the dredging of peat with simple scoops and then the making of turves. Soon other fuels replaced turves in the records and references to turbaries were replaced by references to open water and fisheries.

The archæological evidence put forward by $\mathrm{Mr}$. Charles Green showed that emergence from the Romano-British submergence reached a peak in the thirteenth century. The excavations on the site of the power-station at South Denes, Great Yarmouth, indicate a relative fall in sea-level of the order of $13 \mathrm{ft}$. This means that deep extraction of peat from the Norfolk valley floors was possible in 'dry' pits. Similar evidence revealed a reversal of the downward movement of sea-level, initiated toward the end of the thirteenth century, which clearly accounts for the slow but inexorable flooding of the peat-diggings and the formation of what we now call the Norfolk Broads.

As a piece of scientific detection, the story unfolded to the Norwich symposium was a masterpiece. It is, however, not only of historical or academic interost. The state of dynamic change, which Dr. Lambert showed to underlie all the present-day problems of the Broads, both scientific and practical, stems directly from these surprising beginnings. The vegotation of broadland does not, as was formerly thought, result from the overgrowing of large continuous sheets of open water. There is a fundamental distinction between the vegetation which has grown up on the solid fen, much modified by a variety of human interference, and that which is encroaching on the basin of the Broads. The filling of the manmade lakes with freshwater mud, which has made this encroachment possible, only reached a critical stage about the beginning of the nineteenth century. It has, however, already resulted in a rapid reduction of the open water available to the holiday maker. Dr. Lambert is continuing her ecological work in the Broads, but the number of problems which still remain to be tackled, some of which she touched on, is very largo. The need for more research was the theme of the discussion which followed the reading of papers. Any new work which may be instituted will owe much to Dr. Lambert and Mr. Jennings and their colleagues.

C. KIDson

\section{THE SOIL AS AN ENVIRONMENT FOR ANIMAL LIFE}

A SYMPOSIUM on "The Soil as an Environment for Animal Life" was held on September 1 by Section D (Zoology) at the Norwich meeting of the British Association for the Advancement of Science.

Sir John Russell pointed out that soil contains four groups of components: a minoral framework, organic matter, mineral matter from the bodies of organisms and soil solution. The relative proportions of organic and inorganic substances largely determine the suitability of the soil as a habitat: arable soils, with the lowest organic content, contain fewest organisms, while grasslands are usually richer.

The organic matter is derived from plants, their remains being reduced by organisms in the soil to their original simple origins: residues remaining form the humus. This is black, has colloidal proper- ties, and in the elimate of Great Britain contains about ten times as much carbon as nitrogen. If non-nitrogenous substances are added to the soil, atmospheric nitrogen is fixed, while if nitrogenous substances are added the humus splits off nitrogen as ammonia or nitrogen gas.

The mineral framework of the soil contains particles ranging from $2 \mathrm{~mm}$. to $0.02 \mathrm{~mm}$. in equivalent diameter: these are the sand and silt. Clay particles less than $2 \mu$ in equivalent diameter differ from the larger particles; they carry a negative electric charge, and can attract positively charged ions such as ealcium and hold them against leaching. Clay is colloidal, with a great power of absorbing water: it expands on wetting and shrinks on drying, producing large cracks in the soil. 